\title{
Effect of Different Organic And Inorganic Fertilizers on the Growth and Yield of Wetland Rice
}

\author{
Aziz MA ${ }^{1 *}$, Islam $\mathrm{MJ}^{2}$ and Kashem $\mathrm{MA}^{1}$ \\ ${ }^{1}$ Department of Soil Science, Faculty of Agriculture; ${ }^{2}$ Department of Aquatic Resource Management, Faculty \\ of Fisheries; Sylhet Agricultural University, Sylhet-3100, Bangladesh
}

[Received: November 19, 2015; Accepted: December 08, 2015]

\begin{abstract}
Two experiments were conducted at farmer's field of Tukerbazer, Sylhet in Boro season and T. aman season of 2013 in order to test the effect of different organic and inorganic fertilizers on the growth and yield of wetland rice. Eight treatment combinations were tested in $\mathrm{T}$. aman season namely $\mathrm{T}_{1}=$ Control (without fertilizer), $\mathrm{T}_{2}=$ Agro-Sar (Organo-Chemical) (ASOC) @ 750 kg/ha, $\mathrm{T}_{3}=\mathrm{STB}$ (Soil Test Based), $\mathrm{T}_{4}=\mathrm{T}_{2}+50 \% \mathrm{STB}, \mathrm{T}_{5}=\mathrm{T}_{2}+$ $60 \% \mathrm{STB}, \mathrm{T}_{6}=\mathrm{T}_{2}+70 \% \mathrm{STB}, \mathrm{T}_{7}=\mathrm{T}_{2}+80 \% \mathrm{STB}$ and $\mathrm{T}_{8}=\mathrm{T}_{2}+\mathrm{T}_{3}$ where BRRI dhan31 was used as test crop. In Boro season, the following ten treatment combinations were tested in Boro season: namely $\mathrm{T}_{1}=\mathrm{FRG}{ }^{\prime} 05$ dose: N, P, K, S and Zn @ 123, 26, 60, 13 \& 4 kg/ha, T $=$ Agro meal plus @ 300 kg/ha, $\mathrm{T}_{3}=\mathrm{T}_{2}+\mathrm{N}, \mathrm{P}, \mathrm{K}, \mathrm{S} @$ 74, 16, 60 and $8 \mathrm{~kg} / \mathrm{ha}, \mathrm{T}_{4}=\mathrm{ASO} @ 740 \mathrm{~kg} / \mathrm{ha}, \mathrm{T}_{5}=\mathrm{T}_{4}+\mathrm{N}, \mathrm{P}, \mathrm{K}, \mathrm{S} @ 74,16,60$ and $8 \mathrm{~kg} / \mathrm{ha}, \mathrm{T}_{6}=$ Agro-Sar (Organo-chemical) (ASOC) @ $740 \mathrm{~kg} / \mathrm{ha}, \mathrm{T}_{7}=\mathrm{T}_{6}+\mathrm{N}, \mathrm{P}, \mathrm{K}, \mathrm{S} @$ 94, 18, 36 and 8, T $8=$ Raj Jaibo Sar @ 790 $\mathrm{kg} / \mathrm{ha}, \mathrm{T}_{9}=\mathrm{T}_{8}+\mathrm{N}, \mathrm{P}, \mathrm{K}, \mathrm{S} @ 74,20,54$ and $9 \mathrm{~kg} / \mathrm{ha}$, and $\mathrm{T}_{10}=$ Control (without fertilizer). The blanket doses of fertilizers were applied as soil test based (STB). The experiments were laid out in Randomized Complete Block Design with 3 replications of each treatment. The sources of N, P, K \& S were USG, TSP, MP and gypsum. The treatment $\mathrm{T}_{4}$ where USG was deep-placement produced the maximum yield and also found superior in terms of economic point of view.
\end{abstract}

Key words: Agro-Sar (Organo-Chemical), Fertilizers, Growth and yield parameters, Wetland rice. Rice seasons, Economic analysis.

\section{INTRODUCTION}

Bangladesh is densely populated and agriculture based country. Agriculture is the main source of livelihood for more than $80 \%$ of the country's population. Rice is the staple food crop of the people of Bangladesh covering an area of about 64.52 million hectares, producing about 28.93 million metric tons where the average production is about $2.23 \mathrm{t} \mathrm{ha}^{-1[1]}$. Like other crops, the yield level of rice is very low $\left(2.23 \mathrm{t} \mathrm{ha}^{-1}\right)$ compared to other rice growing developed countries like South Korea and Japan where the average yield is 6.00 and $5.22 \mathrm{t} \mathrm{ha}^{-1}$, respectively ${ }^{[3]}$. Organic matter content of the soils are constantly lessening by repeated farming which leads to hard soil. Nutrient rich organic fertilizer improves soil condition; reduce soil compactness, clotting and erosion. Suitable organic sources of nutrients are necessary for sustainable agriculture that will provide maximum rice production with good quality and maintain a sound environment. Organic matter is the vital component of soil health as well as crop production. Most of the cultivated soil in Bangladesh, organic matter is very low ranging from $0.5-2 \%$ where majority of the cultivated soils is about $1 \%$. Agro-Sar (OrganoChemical) is a nutrient enriched mixed fertilizer. The performance of this fertilizer alongwith other fertilizer combinations was evaluated in Boro and T. aman rice at farmer's field of Tukerbazer, Sylhet in 2013.

\section{MATERIALS AND METHODS}

The experiments were conducted at farmer's field of Tukerbazer, Sylhet in Boro season and T. aman season of 2013. The initial soil properties of the experimental site are presented in Table 1. Soil texture, $\mathrm{pH}$, organic matter, available $\mathrm{P}$ and $\mathrm{S}$, exchangeable $\mathrm{K}, \mathrm{Na}, \mathrm{Ca}$ and $\mathrm{Mg}$ were determined following standard methods ${ }^{[2,5-8]}$. For T. Aman season, the following eight treatment combinations were tested viz. $\mathrm{T}_{1}=$ Control (without fertilizer), $\mathrm{T}_{2}=$ Agro-Sar (Organo-Chemical) (ASOC) @ 750 kg/ha, $\mathrm{T}_{3}=$ STB (Soil Test Based), $\mathrm{T}_{4}=\mathrm{T}_{2}+50 \%$ STB, $\mathrm{T}_{5}=$ $\mathrm{T}_{2}+60 \% \mathrm{STB}, \mathrm{T}_{6}=\mathrm{T}_{2}+70 \% \mathrm{STB}, \mathrm{T}_{7}=\mathrm{T}_{2}+80 \%$ STB and $T_{8}=T_{2}+T_{3}$. The experiment was laid out in a randomized complete block design with three replications having unit plot size of $5 \mathrm{~m} \times 4 \mathrm{~m}$. Fertilizer doses of STB were $93 \mathrm{~kg} \mathrm{~N}, 16 \mathrm{~kg} \mathrm{P}, 20$ $\mathrm{kg} \mathrm{K}$ and $10 \mathrm{~kg} \mathrm{~S} / \mathrm{ha}$, and was applied as Urea, TSP, MP and Gypsum, respectively. BRRI dhan 31 was used as test crop. Thirty day old seedlings where 2-3 
seedling/hill were transplanted maintaining $20 \mathrm{~cm} \mathrm{x}$ $20 \mathrm{~cm}$ spacing.

For Boro season,: the following ten treatment combinations were tested: which are $\mathrm{T}_{1}=\mathrm{FRG}$ '05 dose: N, P, K, S and Zn @ 123, 26, 60, 13 \& 4 kg/ha, required. At maturity, the crop was harvested from 5 $\mathrm{m}^{2}$ area for grain and straw yield and grain yield was adjusted to $14 \%$ moisture content. The plant height, number of tiller, number of panicle, filled and unfilled grain per penicle and grain \& straw yield

Table 1. Initial soil characteristics of the experimental site of Tukerbazer, Sylhet

\begin{tabular}{cc}
\hline Parameters & Soil properties \\
\hline Texture & Sandy loam \\
pH $(1: 2.5)$ & 5.79 \\
Organic C $(\%)$ & 0.80 (Low) \\
Total N $(\%)$ & 0.08 (Very low) \\
Available P(ppm) & 8.6 (low) \\
Exchangeable K(meq/100g soil) & 0.22 (Medium) \\
Available S (ppm) & 6.22 (low) \\
Available Zn $(\mathrm{ppm})$ & 1.5 (high) \\
\hline
\end{tabular}

Table 2. Effect of organic and inorganic fertilizers on the growth and yield of T. Aman rice

\begin{tabular}{cccccccc}
\hline Treatment* & $\begin{array}{l}\text { Plant } \\
\text { height }(\mathrm{cm})\end{array}$ & $\begin{array}{l}\text { Tiller } \\
\text { no./m }\end{array}$ & $\begin{array}{l}\text { Panicle. } \\
\text { no./m }\end{array}$ & $\begin{array}{l}\text { Sterility } \\
(\%)\end{array}$ & $\begin{array}{l}1000 \text { grain } \\
\text { wt. }\end{array}$ & $\begin{array}{l}\text { Grain } \\
\text { Yield(t/ha })\end{array}$ & $\begin{array}{l}\text { Straw } \\
\text { Yield (t/ha) }\end{array}$ \\
\hline T1 & 94 & 173 & 159 & 32 & 26.3 & 3.10 & 3.19 \\
T2 & 100 & 202 & 184 & 30 & 26.8 & 3.54 & 3.95 \\
T3 & 105 & 198 & 185 & 36 & 26.3 & 3.55 & 4.05 \\
T4 & 101 & 194 & 178 & 32 & 27.0 & 3.70 & 3.94 \\
T5 & 103 & 186 & 178 & 36 & 26.8 & 3.77 & 4.07 \\
T6 & 105 & 209 & 188 & 31 & 26.8 & 3.69 & 3.99 \\
T7 & 106 & 236 & 218 & 32 & 26.9 & 3.70 & 4.65 \\
T8 & 109 & 214 & 197 & 28 & 26.8 & 3.48 & 4.32 \\
LSD (5\%) & 3.5 & 40 & 30 & 6 & 1.2 & 0.37 & 0.79 \\
\hline
\end{tabular}

$* \mathrm{~T}_{1}=$ Control (Without fertilizer), $\mathrm{T}_{2}=$ Agro-Sar (Organo-Chemical) (ASOC) @ 7
$\mathrm{STB}, \mathrm{T}_{5}=\mathrm{T}_{2}+60 \% \mathrm{STB}, \mathrm{T}_{6}=\mathrm{T}_{2}+70 \% \mathrm{STB}, \mathrm{T}_{7}=\mathrm{T}_{2}+80 \% \mathrm{STB}$ and $\mathrm{T}_{8}=\mathrm{T}_{2}+\mathrm{T}_{3}$

$\mathrm{T}_{2}=$ Agro meal plus @ $300 \mathrm{~kg} / \mathrm{ha}, \mathrm{T}_{3}=\mathrm{T}_{2}+\mathrm{N}, \mathrm{P}, \mathrm{K}$, $\mathrm{S} @ 74,16,60$ and $8 \mathrm{~kg} / \mathrm{ha}, \mathrm{T}_{4}=\mathrm{ASO} @ 740 \mathrm{~kg} / \mathrm{ha}$, $\mathrm{T}_{5}=\mathrm{T}_{4}+\mathrm{N}, \mathrm{P}, \mathrm{K}, \mathrm{S} @ 74,16,60$ and $8 \mathrm{~kg} / \mathrm{ha}, \mathrm{T}_{6}=$ Agro-Sar (Organo-chemical) (ASOC) @ $740 \mathrm{~kg} / \mathrm{ha}$, $\mathrm{T}_{7}=\mathrm{T}_{6}+\mathrm{N}, \mathrm{P}, \mathrm{K}, \mathrm{S} @ 74,18,36$ and 8, $\mathrm{T}_{8}=\mathrm{Raj}$ Jaibo Sar @ 790 kg/ha, T $=\mathrm{T}_{8}+\mathrm{N}, \mathrm{P}, \mathrm{K}, \mathrm{S} @ 74$, 20, 54 and $9 \mathrm{~kg} / \mathrm{ha}$, and $\mathrm{T}_{10}=$ Control (without fertilizer). The experiment was laid out in a randomized complete block design with three replications using unit plot size of $5 \mathrm{~m} \mathrm{x} 4 \mathrm{~m}$. BRRI dhan 29 was used as test crop. Fifty day old seedling where 2-3 seedling/hill were transplanted maintaining $20 \mathrm{~cm}$ x $20 \mathrm{~cm}$ spacing. Fertilizers TSP, MP, Gypsum, and Agro-Sar (Organo-chemical) were applied at final land preparation in the both experiments. Urea was applied into three equal splits like $1 / 3$ basal, $1 / 3$ rd maximum tillering stage and the remaining $1 / 3 \mathrm{rd}$ at panicle initiation stage. Intercultural operations were done when it was were recorded. The data were analyzed following randomized complete block design and mean separation was done by DMRT ${ }^{[4]}$. Finally, economic analyses were done for net benefit and marginal rate of return.

\section{RESULTS AND DISCUSSION}

\section{Growth and Yield}

T. Aman season:

Application of Agro-Sar (Organo-Chemical) alone or in combination with chemical fertilizer increased the plant height of rice over control. Highest plant height $(109 \mathrm{~cm})$ was found in treatment $\mathrm{T}_{8}$ followed by treatment $\mathrm{T}_{7}(106 \mathrm{~cm})$ Application of chemical fertilizer on STB alone or in combination with ASOC did not statistically increase the tiller and panicle number of rice over control. Maximum number of tiller (236) was recorded in treatment $\mathrm{T}_{7}$ 
followed by treatment $T_{8}$ (214). On the other hand treatment $\mathrm{T}_{7}$ produced the highest number of panicle. (218) followed by $\mathrm{T}_{8}$ (197) (Table 2). Minimum number of unfilled grain $(28 \%)$ was observed in treatment $\mathrm{T}_{8}$ followed by $\mathrm{T}_{2}$. Application of ASOC alone or in combination with chemical fertilizer on STB significantly increased the grain yield of rice over control. Maximum grain yield (3.77 t/ha) was recorded in treatment $T_{5}$ followed by treatment $T_{4}$ and $\mathrm{T}_{7}$. Highest straw yield (4.65 t/ha) was found in treatment $\mathrm{T}_{7}$ followed by treatment $\mathrm{T}_{5}$.

It is found from the results that 40 to $50 \%$ reduction of chemical fertilizer along with ASOC @ $750 \mathrm{~kg} / \mathrm{ha}$ may be a good combination of organic and inorganic plus@ @ 300 kg/ha) was at per with other organic based treatments where supplemented reduced amount of chemical fertilizers. It was found from the Table 3 that the grain yield was significantly affected by different treatments. The highest grain yield (7.41 $\mathrm{t} / \mathrm{ha}$ ) was obtained in treatment $\mathrm{T}_{5}$ followed by treatment $T_{9}, T_{3}$ and $T_{7}$ (which was statistically similar with $\mathrm{T}_{5}$. In contrast, the lowest grain yield ( $3.53 \mathrm{t} / \mathrm{ha}$ ) was found in the treatment $\mathrm{T}_{10}$ (control). It was observed that grain yield was higher in the treatments where chemical fertilizers were applied along with organic fertilizers. Application of organic fertilizers could not produce comparable yield with the FRG '05 dose $\left(T_{1}\right)$, indicated that the higher yield

Table 3. Effect of organic and inorganic fertilizers on the growth and yield of Boro rice

\begin{tabular}{|c|c|c|c|c|c|}
\hline Treatment* & Panicle/m2 & $\%$ Sterility & $\begin{array}{r}1000 \text { grain } \\
\text { weight }(\mathrm{gm}) .\end{array}$ & $\begin{array}{l}\text { Grain Yield } \\
(\mathrm{t} / \mathrm{ha})\end{array}$ & $\begin{array}{c}\text { Straw Yield } \\
(\mathrm{t} / \mathrm{ha})\end{array}$ \\
\hline $\mathrm{T} 1$ & 303 & 19 & 22 & 6.70 & 7.60 \\
\hline $\mathrm{T} 2$ & 237 & 20 & 20 & 4.34 & 5.34 \\
\hline T3 & 307 & 20 & 22 & 6.92 & 7.92 \\
\hline $\mathrm{T} 4$ & 242 & 16 & 20 & 4.65 & 5.65 \\
\hline T5 & 324 & 22 & 22 & 7.41 & 8.41 \\
\hline T6 & 225 & 17 & 21 & 4.22 & 5.22 \\
\hline $\mathrm{T} 7$ & 306 & 19 & 22 & 6.77 & 7.77 \\
\hline $\mathrm{T} 8$ & 227 & 17 & 21 & 4.47 & 5.47 \\
\hline T9 & 323 & 17 & 22 & 7.20 & 8.20 \\
\hline T10 & 194 & 21 & 20 & 3.53 & 4.58 \\
\hline $\operatorname{LSD}(5 \%)$ & 58 & 4 & 0.78 & 0.47 & 0.56 \\
\hline
\end{tabular}

* $\mathrm{T}_{1}=$ FRG '05 dose: N, P, K, S and Zn@ @ 123, 26, 60, 13 \& 4 kg/ha, T $=$ Agro meal plus @ 300 kg/ha, T $3=\mathrm{T}_{2}+\mathrm{N}, \mathrm{P}, \mathrm{K}, \mathrm{S} @ 74$, 16, 60 and $8 \mathrm{~kg} / \mathrm{ha}, \mathrm{T}_{4}=$ ASO @ $740 \mathrm{~kg} / \mathrm{ha}, \mathrm{T}_{5}=\mathrm{T}_{4}+\mathrm{N}, \mathrm{P}, \mathrm{K}, \mathrm{S} @ 74,16,60$ and $8 \mathrm{~kg} / \mathrm{ha}, \mathrm{T}_{6}=$ Agro-Sar (Organo-chemical) (ASOC) @ 740 kg/ha, T $7=\mathrm{T}_{6}+\mathrm{N}, \mathrm{P}, \mathrm{K}, \mathrm{S} @ 74,18,36$ and 8, T $8=$ Raj Jaibo Sar @ $790 \mathrm{~kg} / \mathrm{ha}, \mathrm{T}_{9}=\mathrm{T}_{8}+\mathrm{N}, \mathrm{P}, \mathrm{K}, \mathrm{S} @ 74,20,54$ and $9 \mathrm{~kg} / \mathrm{ha}$, and $\mathrm{T}_{10}=$ Control(Without fertilizer).

fertilizer for producing reasonable higher yield.

Boro season:

Different organic and organo-chemical/chemical fertilizers had significant role in production of panicle $/ \mathrm{m}^{2}$ (Table 3). Panicle production per unit area was statistically higher in the treatments where chemical fertilizers applied along with organic fertilizer compared to the treatments where only organic fertilizer applied. The lowest panicle per unit area (194) was observed in treatment $\mathrm{T}_{10}$ (Control) which was about $20 \%$ less than the organic based treatments. However, panicle $/ \mathrm{m}^{2}$ in $\mathrm{T}_{2}$ (Agro meal can only be achieved when organic fertilizers and chemical fertilizers are applied together.

\section{Economic analysis: \\ Net benefit}

Economic analysis on partial budget of the experiments is presented in Table $4 \& 5$. The net benefit of each treatment is calculated by subtracting the total costs that vary from the gross field benefit. The total costs are the sum of all the costs that vary for a particular treatment. The maximum net benefit $(88 \%)$ was achieved in treatment $\mathrm{T}_{5}$ followed by $\mathrm{T}_{3}$ 
Table 4. Economic analysis of partial budget against different treatments of T.Aman rice

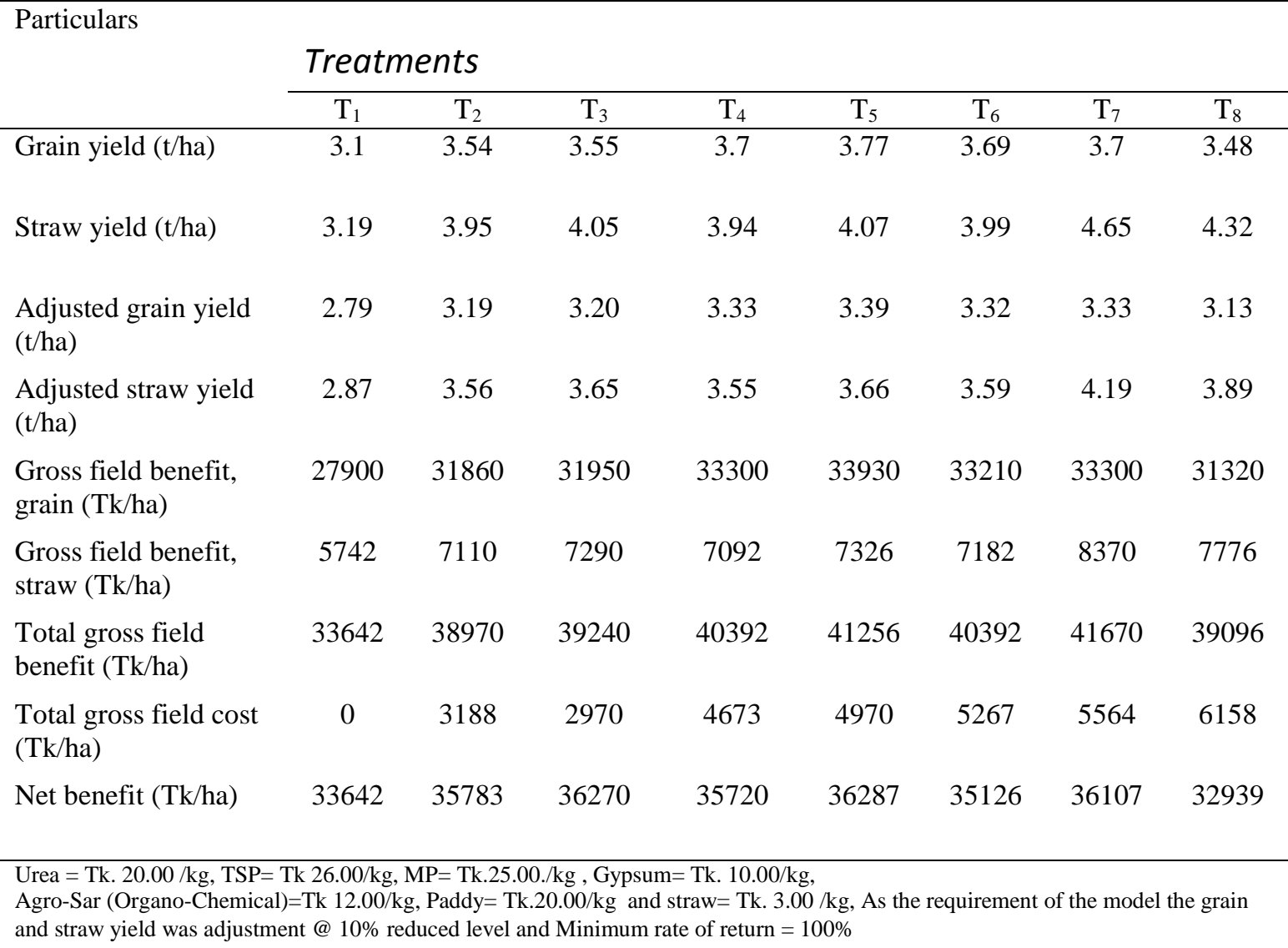

(T. Aman season). The highest net benefit was found in $\mathrm{T}_{5}$ followed by $\mathrm{T}_{3}$ (Boro season).

\section{Dominance and marginal analysis}

The analysis has been done in stepwise manner, passing from the treatment with the lowest costs that vary to the next consideration. As the increase in cost, the net benefit would be 
increased but the net benefits are lower in $\mathrm{T}_{2}, \mathrm{~T}_{4}, \mathrm{~T}_{6}$, $\mathrm{T}_{7}$ and $\mathrm{T}_{8}$ as the cost increased. Thus, $\mathrm{T}_{2}, \mathrm{~T}_{4}, \mathrm{~T}_{6}, \mathrm{~T}_{7}$ and $T_{8}$ are cost dominated treatments and can be eliminated for further consideration (Table $6, \mathrm{~T}$. Aman season). Similarly, $\mathrm{T}_{1}, \mathrm{~T}_{6}, \mathrm{~T}_{7}, \mathrm{~T}_{8}$ and $\mathrm{T}_{9}$ treatment are cost dominated treatment and can be eliminated for further consideration (Table 7, Boro season). It is well known that the minimum marginal rate of return for the crop is $100 \%$. If the marginal rate of return of the change from the first to the second treatment is equal or above the minimum marginal rate of return then the next comparison has been made between second and third treatment (not between first and third). This comparison has been continued (i.e. increasing level of investment) until the marginal rate of return falls below the minimum rate of return.

In the experiment, the maximum marginal rate of return was recorded between $\mathrm{T}_{1}$ and $\mathrm{T}_{3}$ is $88 \%$. It is indicated that farmers will continue to invest as long indicate farmers will continue to invest as long as the returns to each extra unit invested (measured by MRR) which are higher than the cost of the extra invested (measured by the minimum acceptable rate of return) (Table 7). Thus, it can be concluded that $\mathrm{T}_{4}$ is the most economically viable treatment of the experiment.

\section{CONCLUSION}

In T. Aman season, STB fertilization appeared to be the economically most viable treatment although the treatment $\mathrm{T}_{4}$ and $\mathrm{T}_{5}$ that produced higher yield than that of STB. In Boro season, treatment $\mathrm{T}_{7}$ where ASOC applied along with reduced rate of chemical fertilizer produced substantially higher yield. Integrated use of organic and inorganic fertilizer is essential for sustainable increased crop production and improved soil fertility. In addition, reduced use of chemical fertilizer may positively influences the environment through reducing contamination of air,

Table 5. Economic analysis of partial budget against different treatments of Boro rice Particulars

\section{Treatments}

\begin{tabular}{|c|c|c|c|c|c|c|c|c|c|c|}
\hline & $\mathrm{T}_{1}$ & $\mathrm{~T}_{2}$ & $\mathrm{~T}_{3}$ & $\mathrm{~T}_{4}$ & $\mathrm{~T}_{5}$ & $\mathrm{~T}_{6}$ & $\mathrm{~T}_{7}$ & $\mathrm{~T}_{8}$ & $\mathrm{~T}_{9}$ & $\mathrm{~T}_{10}$ \\
\hline Grain yield (t/ha) & 6.7 & 4.34 & 6.92 & 4.65 & 7.41 & 4.22 & 6.77 & 4.47 & 7.2 & 3.53 \\
\hline Straw yield (t/ha) & 7.6 & 5.34 & 7.92 & 5.65 & 8.41 & 5.22 & 7.77 & 5.47 & 8.2 & 4.58 \\
\hline $\begin{array}{l}\text { Adjusted grain yield } \\
(\mathrm{t} / \mathrm{ha})\end{array}$ & 6.03 & 3.91 & 6.23 & 4.19 & 6.67 & 3.80 & 6.09 & 4.02 & 6.48 & 3.18 \\
\hline $\begin{array}{l}\text { Adjusted straw yield } \\
(\mathrm{t} / \mathrm{ha})\end{array}$ & 6.84 & 4.81 & 7.13 & 5.09 & 7.57 & 4.70 & 6.99 & 4.92 & 7.38 & 4.12 \\
\hline Gross field benefit, & 4824 & 3124 & 4982 & 3348 & 5335 & 3038 & 4874 & 3218 & 5184 & 2541 \\
\hline grain $(\mathrm{Tk} / \mathrm{ha})$ & 0 & 8 & 4 & 0 & 2 & 4 & 4 & 4 & 0 & 6 \\
\hline $\begin{array}{l}\text { Gross field benefit, } \\
\text { straw (Tk/ha) }\end{array}$ & 6840 & 4806 & 7128 & 5085 & 7569 & 4698 & 6993 & 4923 & 7380 & 4122 \\
\hline Total gross field & 5508 & 3605 & 5695 & 3856 & 6092 & 3508 & 5573 & 3710 & 5922 & 2953 \\
\hline benefit (Tk/ha) & 0 & 4 & 2 & 5 & 1 & 2 & 7 & 7 & 0 & 8 \\
\hline $\begin{array}{l}\text { Total gross field cost } \\
\text { (Tk/ha) }\end{array}$ & 5160 & 1200 & 3780 & 2960 & 6056 & 2960 & 6382 & 3160 & 6996 & 0 \\
\hline \multirow[t]{2}{*}{ Net benefit (Tk/ha) } & 4992 & 3485 & 5317 & 3560 & 5486 & 3212 & 4935 & 3394 & 5222 & 2953 \\
\hline & 0 & 4 & 2 & 5 & 5 & 2 & 5 & 7 & 4 & 8 \\
\hline
\end{tabular}

Urea $=$ Tk. $20.00 / \mathrm{kg}, \mathrm{TSP}=\mathrm{Tk} 26.00 / \mathrm{kg}, \mathrm{MP}=\mathrm{Tk} .25 .00 . / \mathrm{kg}$, Gypsum= Tk. 10.00/kg,

Agro-Sar (Organo-chemical) $=$ Tk $12.00 / \mathrm{kg}$, Paddy $=\mathrm{Tk} 20.00 / \mathrm{kg}$ and straw $=\mathrm{Tk} .3 .00 / \mathrm{kg}$, As the requirement of the model the grain and straw yield was adjustment @ 10\% reduced level and Minimum rate of return $=100 \%$

as the returns to each extra unit invested (measured by MRR) which are higher than the cost of the extra invested (measured by the minimum acceptable rate of return) (Table 6). Thus, it can be concluded that $\mathrm{T}_{3}$ is the most economically viable treatment of the experiment (T. Aman). For Boro season, the maximum marginal rate of return between $\mathrm{T}_{4}$ and $\mathrm{T}_{3}$ is $2142 \%$ well above the $100 \%$ minimum. That soil and water. Considering these points, it may be suggested that 40 to $50 \%$ reduction of chemical fertilizer on STB along with ASOC @ $750 \mathrm{~kg} / \mathrm{ha}$ may be a good combination of organic and inorganic fertilizer for sustaining soil fertility and increasing $\mathrm{T}$. aman and Boro rice. 
Table 6. Dominance and marginal analysis on growth and yield against different treatments of T. Aman rice

\begin{tabular}{llll}
\multicolumn{1}{c}{ Treatments* } & Total costs that vary Net benefit (Tk./ha) & $\begin{array}{l}\text { Marginal rate of return } \\
\text { (Tk./ha) }\end{array}$
\end{tabular}

\begin{tabular}{lcc}
\hline T1 & 0 & 33642 \\
T3 & 2970 & 36270 \\
T2 & 3188 & $35783 \mathrm{D}$ \\
T4 & 4673 & $35720 \mathrm{D}$ \\
T5 & 4970 & 36287 \\
T6 & 5267 & $35126 \mathrm{D}$ \\
T7 & 5564 & $36107 \mathrm{D}$ \\
T8 & 6158 & $32939 \mathrm{D}$ \\
\hline
\end{tabular}

$\mathrm{D}=$ Dominated $* \mathrm{~T}_{1}=$ Control, $\mathrm{T}_{2}=$ Agro-Sar (Organo-Chemical) (ASOC) @ 750 kg/ha, $\mathrm{T}_{3}=\mathrm{STB}$ (Soil Test Based), $\mathrm{T}_{4}=\mathrm{T}_{2}+50 \%$ $\mathrm{STB}, \mathrm{T}_{5}=\mathrm{T}_{2}+60 \% \mathrm{STB}, \mathrm{T}_{6}=\mathrm{T}_{2}+70 \% \mathrm{STB}, \mathrm{T}_{7}=\mathrm{T}_{2}+80 \% \mathrm{STB}$ and $\mathrm{T}_{8}=\mathrm{T}_{2}+\mathrm{T}_{3}$.

Table 7. Dominance and marginal analysis on growth and yield against different treatments of Boro rice

\begin{tabular}{ccc} 
Treatments* $^{*} \begin{array}{c}\text { Total costs that } \\
\text { (Tk./ha) }\end{array}$ & vary & Net benefit (Tk./ha) \\
\hline T10 & 0 & 29538 \\
T2 & 1200 & 34854 \\
T6 & 2960 & $32122 \mathrm{D}$ \\
T4 & 2960 & 35605 \\
T8 & 3160 & $33947 \mathrm{D}$ \\
T3 & 3780 & 53172 \\
T1 & 5160 & $49920 \mathrm{D}$ \\
T5 & 6056 & 54865 \\
T7 & 6382 & $49355 \mathrm{D}$ \\
T9 & 6996 & $52224 \mathrm{D}$
\end{tabular}

D=Dominated; $* T_{1}=$ FRG '05 dose: N, P, K, S and Zn @ 123, 26, 60, 13 \& 4 kg/ha, T $=$ Agro meal plus @ 300 kg/ha, T $3=\mathrm{T}_{2}+\mathrm{N}$,

$\mathrm{P}, \mathrm{K}, \mathrm{S} @ 74,16,60$ and $8 \mathrm{~kg} / \mathrm{ha}, \mathrm{T}_{4}=\mathrm{ASO} @ 740 \mathrm{~kg} / \mathrm{ha}, \mathrm{T}_{5}=\mathrm{T}_{4}+\mathrm{N}, \mathrm{P}, \mathrm{K}, \mathrm{S} @ 74,16,60$ and $8 \mathrm{~kg} / \mathrm{ha}$, T $6=$ Agro-Sar $($ Organochemical) (ASOC) @ 740 kg/ha, T $7=T_{6}+\mathrm{N}, \mathrm{P}, \mathrm{K}, \mathrm{S} @ 74,18,36$ and 8, T $=$ Raj Jaibo Sar @ 790 kg/ha, T $=$ T 8 + N, P, K, S @ $74,20,54$ and $9 \mathrm{~kg} / \mathrm{ha}$, and $\mathrm{T}_{10}=$ Control (Without fertilizer).

\section{REFERENCES}

1. BBS (Bangladesh Bureau of Statistics) (2008). The Yearbook of Agricultural Statistics of Bangladesh. Statistics Div., Minis. Plan. Govt. peoples Repub., Bangladesh, Dhaka. 129p.

2. Black CA (1965). Methods of soil analysis. Part I and II. Amer. Soc. Agron. Inc. Pub., Madison. USA

3. FAO (Food and Agriculture Organization) (2004). FAO Indices of Food and Agricultural Production. Food Agric. Org., Italy. pp. 18-19.

4. Gomez KA and Gomez AA (1984). Statistical Procedures for Agricultural Research. 2nd Edn. An Wiley Intl. Sci. Pub., John and Sons. New York. 680p.

5. Jackson ML (1962). Soil Chemical Analysis. Constable and Co. Ltd. London.
6. Olsen S R, Cole C V, Watanable F S and Dean L A (1954). Estimation of available phosphorus in soils by extraction with sodium carbonate U.S. Dept. Agr. (Circ.) pp: 929.

7. Page AL, Miller RH and Keeney DR (1982). Methods of Soil Analysis Part 2. $2^{\text {nd }}$ Ed. Am. Soc. Agron. Increased. Madison. Wisconsin, USA.

8. Walkley A and Black AI (1935). An examination of the Degtijaref method for determining soil organic matter and a proposed modification of the chromic acid titration method. Soil Sci., 37: 29-38. 